\title{
Die Verkrummeling VAN Die AugustiniaAnse PARADigma in DiE TEOLOGIE? 'N KRITIESE BESPREKING VAN CORNELIS BLOM SE BOEK ZONDER GROND ONDER DE VOETEN
}

\author{
Author: \\ Izak (Sakkie) J.J. \\ Spangenberg ${ }^{1}$
}

\section{Affiliation:}

${ }^{1}$ Departement Old

Testament and Ancient

Near Eastern Studies,

University of South Africa,

South Africa

\section{Correspondence to:}

Sakkie Spangenberg

email:

spangijj@unisa.ac.za

\section{Postal address:}

Department of Old

Testament \& Ancient Near

Eastern Studies, UNISA,

PO Box 392, Pretoria 0003,

South Africa

\section{Keywords:}

Book of Job; Creation; Evil;

Genesis 1-4; Original sin

\section{Dates:}

Received: 03 May 2010

Accepted: 25 July 2010

Published: 14 Sept. 2010

How to cite this article: Spangenberg, I.J.J., 2010, 'Die verkrummeling van die Augustiniaanse paradigma in die teologie? ' $n$ Kritiese bespreking van Cornelis Blom se boek Zonder grond onder de voeten', HTS Teologiese Studies/Theological Studies 66(1), Art. \#848, 7 pages. DOI: $10.4102 /$ hts.v66i1.848

\section{This article is available} at: http://www.hts.org.za
C 2010 . The Authors. Licensee: OpenJournals Publishing. This work is licensed under the Creative Commons Attribution License.

\section{ABSTRACT}

The crumbling of the Augustinian paradigm of theology? A critical discussion of Cornelis Blom's book Zonder grond onder de voeten

The book Zonder grond onder de voeten (i.e. Without any foundation) is the published doctoral thesis which Cornelis Blom submitted at the Free University of Amsterdam. It focuses on evil in creation, and addresses the question: Who is responsible - God or humans? Christian theologians used to conclude (after reading Genesis 1-3) that humans are responsible. Blom, however, takes his cue from the book of Job, and comes to a totally different conclusion. According to his reading of Job and Genesis 1-4, there was no 'fall' from a perfect world. Evil existed right from the beginning, and God did not banish it from the world in which humans have to live. The article raises a number of questions concerning Blom's approach, analyses and conclusions.

\section{INLEIDING}

Onmiddellik ná die lees van die boek Zonder grond onder de voeten (Blom 2009) het Philip Kennedy se woorde 'As Christianity begins its twenty-first century, its Augustinian paradigm of theology has met the fate of the Berlin Wall' (2006:252) my te binne geskiet. Met die uitdrukking 'Augustiniaanse paradigma' vat hy die kern van die Westerse teologie sedert Augustinus (354-430) saam, en som dit dan met hierdie woorde op: 'sondeval-verlossing-eindoordeel'.

Blom se boek is ' $n$ gepubliseerde proefskrif waarmee hy aan die Vrije Universiteit Amsterdam gepromoveer het. Hy gebruik weliswaar nie die uitdrukking 'Augustiniaanse paradigma' nie en maak ook nie die stelling dat hierdie paradigma aan die verkrummel is nie. Tog is dit deur sy hele boek duidelik dat hy hom wél met dié paradigma besig hou, en dat die idee van 'n perfekte skepping en ' $n$ sondeval volgens hom géén grond onder die voete het nie.

Die idee van 'n sondeval is tradisioneel uit Genesis 1-4 afgelees, en Augustinus word as die groot argitek daarvan beskou (Durand 1978:49). Blom (2009) verklaar dat hy nie uitsluitlik op die interpretasie van hierdie gedeelte wil fokus nie, maar dat hy wil deurstoot na die vraag na God en die mens se verantwoordelikheid vir die kwaad in die skepping. In sy eie woorde:

In deze studie gaat het niet alleen om de juistheid van het schema van schepping en zondeval en de interpretatie van Genesis 1-4 die daarbij hoort, maar ook om de vraag hoe we moeten spreken over God en mens in relatie tot het kwaad. Het gaat me niet alleen om de exegese van Genesis 1-4, maar ook om de theologische implicaties. De centrale vraag in dit onderzoek is: wat is de verantwoordelikheid van God voor het kwaad in de wereld?

(Blom 2009:12)

Die proefskrif is dus meer as net ' $n$ eksegetiese studie van Genesis 1-4. Dit wil ook ' $n$ teologiese studie wees. Dit worstel met die vraag na God se verantwoordelikheid vir kwaad in die skepping. Dit is dus ' $n$ soort teodisee, maar dan nie ' $n$ teodisee waarin die antwoord, naamlik dat God kwyt te skeld is van enige verantwoordelikheid vir die kwaad in die wêreld, klaar vasstaan nie (Blom 2009:15). In sy bespreking van die saak wys hy daarop dat verantwoordelikheid in tweërlei sin verstaan kan word, naamlik (1) verantwoordelik in die sin van veroorsaak en (2) verantwoordelik in die sin van aanspreeklik wees. Wat laasgenoemde betref, wys hy op ministeriële verantwoordelikheid in die politiek. ' $n$ Minister is nie verantwoordelik in die sin dat hy/sy iets veroorsaak het nie, maar in die sin dat hy/sy $\mathrm{pa} / \mathrm{ma}$ moet staan vir dade wat ander gedoen of nagelaat het om te doen (Blom 2009:12).

\section{DIE STRUKTUUR EN INHOUD VAN DIE PROEFSKRIF}

Die proefskrif bestaan uit vyf hoofstukke. Dit begin met ' $n$ inleiding waarin die navorsingsprobleem uitgespel word (Blom 2009:11-16). Die probleem fokus op die vraag na die kwaad in die skepping. Wie is daarvoor verantwoordelik - die mens of God? Hierdie vraag is in die tradisionele Christelike teologie aan die hand van Genesis 1-4 beantwoord, en die mens is as die verantwoordelike party uitgewys. God het ' $n$ volmaakte skepping daargestel, maar die mens het met een onbesonne daad die goeie skepping be-duiwel. God is van alle blaam te onthef.

Blom meen egter dat dié tradisionele verklaring nie op 'n stewige grondslag berus nie. Dit het nie 'grond onder die voete' nie - vandaar die titel van die proefskrif, Zonder grond onder de voeten. Volgens hom bied die boek Job 'n beter oplossing vir die vraag na wie vir die kwaad in die skepping verantwoordelik is. Die boek Job bied egter so ' $n$ goeie antwoord dat dit as ' $n$ hermeneutiese sleutel vir die ontsluiting van die betekenis van Genesis 1-4 kan dien. Die antwoord wat die boek Job op die vraag na die kwaad bied, is na regte ook in voormelde Genesis-hoofstukke vasgelê. Lesers moet net 
leer om die antwoord wat die tradisionele teologie bied, links te laat en om Genesis 1-4 met nuwe oë - of 'n beter bril - te lees. Die boek Job bied aan lesers hierdie beter bril. Dáár sien ons dat die vriende geen grond onder hulle voete het om Job te veroordeel nie. Job ly nie omdat hy gesondig het of ' $n$ sondaar is nie. Die vergeldingsleer kan nie as basis dien om sy lyding mee te verklaar nie. God erken met soveel woorde (of liewer deur sy handeling om Job dubbel te vergoed) dat Hy verkeerd gehandel het deur die Satan se uitdaging te aanvaar (Blom 2009:113).

Ná die uitvoerige bespreking van die boek Job (Blom 2009:17120), kom Genesis 1-4 aan die bod. Hierdie Skrifgedeelte word in twee afsonderlike hoofstukke in die proefskrif behandel, naamlik hoofstuk 3 (Gen 1) en hoofstuk 4 (Gen 2-4). In hierdie hoofstukke behandel hy ál die kwessies wat in die tradisionele Christelike teologie aan die hand van hierdie Skrifgedeelte geopper word. Hy vat dit in die volgende sewe punte saam (Blom 2009):

- Skepping uit niks (creatio ex nihilo).

- Die skepping was van die begin af volmaak (goed/onverbeterlik).

- Die mens self was in morele sin ' $n$ volmaakte wese. Hy was vry van sonde en het geweet wat goed en kwaad behels.

- Daar was tot en met die sondeval géén kwaad in die skepping nie.

- Die naaktheid van die mens, en die feit dat man en vrou hulle aanvanklik nie vir mekaar geskaam het nie, dui op die oorspronklike onskuld en volmaaktheid van die mens.

- Omdat die mens die kroon van die skepping is, het hy met sy sondige daad die ganse goeie skepping be-duiwel, en het die dood sy intrede in die skepping gemaak.

- Die tradisionele teologie werk met die drieslag skepping-sondevalverlossing (herskepping).

(Blom 2009:122-124)

In hoofstuk 3 (Gen 1) kom die volgende ter sprake: skepping uit niks (creatio ex nihilo); die 'woes en leeg wees' van die aarde; die mens as 'beeld van God'; die voedselopdrag, en die opdrag om oor alles te heers (Blom 2009:121-218). In hoofstuk 4 (Gen 2-4) behandel Blom die tuin van Eden; die skepping van die mens as man en vrou; die 'sondeval', die gevolge daarvan, en die rol van die slang; die naaktheid van die mens, en watter betekenis daaraan geheg moet word, en die rol van God in dié gebeure (Blom 2009:219-266).

Hoofstuk 5, wat dieselfde titel dra as die proefskrif, bied 'n samevatting en 'n antwoord op die aanvanklike navorsingsvraag, naamlik 'Wie is verantwoordelik vir die kwaad in die skepping?' (Blom 2009:267-282).

\section{DIE VERHAAL VAN JOB AS HERMENEUTIESE SLEUTEL}

Blom maak 'n interessante keuse deur die boek Job (en die verhouding wat daar tussen God en 'n lydende mens ontvou) as hermeneutiese sleutel te gebruik om Genesis 1-4 te lees en om die vraag na wie verantwoordelik is vir kwaad in die skepping te probeer beantwoord.

Hy wy 'n raps meer as honderd bladsye aan die boek Job, en wys aan die begin van die bespreking daarop dat hy Tsevat en Gutiérrez se siening onderskryf. Volgens dié twee uitleggers speel die aantyging van die Satan (of teenstander), naamlik dat Job God nie sonder goeie rede dien nie (Job 1:9-11), deur die hele boek 'n rol. Die vraag wat in die agtergrond (oftewel in die hemel) gevra word, beïnvloed die gesprekke wat op die voorgrond (op aarde) afspeel. Bezuidenhout (1986) het in sy ongepubliseerde proefskrif ook daarop gewys dat dít die geval is - maar daar is meer op die spel. Die boek behoort tot die Israelitiese wysheidsliteratuur, en dáárin speel die vergeldingsleer 'n groot rol. Volgens hierdie leer het goeie dade goeie gevolge, en slegte dade slegte gevolge. Die vraag of Job God sonder rede dien, word dus aan die hand van die vergeldingsleer bespreek. Die boek Job hoort egter tuis onder daardie deel van die wysheidsliteratuur wat téén die vergeldingsleer protesteer. Die skrywer van die boek Job onderstreep (aan die hand van hoe die verhaal ontvou) dat die vergeldingsleer hom in die geval van Job te pletter loop. Hy ly om geen goeie rede nie - behalwe as ' $n$ mens aanvaar dat daar magte en kragte agter die sigbare wêreld is wat mense se lewensloop en -lot bepaal. Die skrywer van die boek Job het dit wél aanvaar, en skryf Job se lyding toe aan 'n uitdaging in die hemel. Die Satan is oortuig dat Job God dien omdat dit vir hom voordelig is: God seën hom en laat hom suksesvol en voorspoedig wees - daarom is hy vroom. God ontken dit, maar aanvaar die uitdaging om Job aan ' $n$ toets te onderwerp. Daar moet bepaal word of sy vroomheid belangeloos is en nie dalk 'vroomheid om voordeel' nie. Job se vriende neem die vergeldingsleer as uitgangspunt in hul gesprekke, en argumenteer dat Job se lyding met verkeerde dade in sy verlede verband hou. Lyding moet ' $n$ oorsaak hê en die oorsaak moet in Job se lewenswyse en handelinge gesoek word.

Blom se bespreking van die boek Job het heelwat om die lyf, en wat hierbo daaroor geskryf is, maak 'n groot deel van sy bespreking uit. Dit is dus die moeite werd om dit te lees, maar daar is ' $n$ aantal uitgangspunte en stellings wat problematies is. Eerstens maak hy dikwels die stelling dat Job se vriende aanvaar dat hy 'n sondaar is, terwyl hulle bloot argumenteer dat hy sonde gedoen het: 'Jobs vrienden menen dus dat het niet onrechtvaardig is dat Job lijdt. Hij is een zondaar en heeft daarom dit lijden verdiend' (Blom 2009:58). Vergelyk ook die volgende stellings: 'Elifaz en zijn vrienden zijn ervan overtuigd dat geen mens zonder zonde is' (Blom 2009:65), en 'Voor Elifaz en zijn vrienden staat Jobs schuld vast. Job is een zondaar ...' (Blom 2009:69). Na my mening getuig hierdie soort formulerings dat Blom hom steeds nie van die tradisionele Christelike mensbeskouing (dat mense sondaars is) kon losmaak nie. Hy tref nie die broodnodige onderskeid tussen sondaar wees en sonde doen nie. Den Heyer (2003:238) het gelyk: 'In de oudtestamentisch-joodse traditie "doet" de mens zonde, terwijl in de christelijke traditie de gedachte van erfzonde ertoe heeft geleid dat de mens van "nature" een zondaar "is".' Dit gaan in die dialoë nie oor die feit dat Job 'n sondaar is nie, maar dat hy sonde gedoen het. Job se onskuldverklaring kan as bewys dien dat hy hom verset teen die vriende se beskuldiging dat hy verkeerd gehandel het (vgl Job 22:6-11 met Job 29:12-19).

Tweedens slaan Blom nie ag op die ontwikkelingsgeskiedenis van die boek Job nie. Volgens hom is die boek ' $n$ eenheid, en moet ' $n$ mens dit as sodanig lees. Hy neem nie in ag dat die boek uit ' $n$ raamvertelling (Job 1:1-2:13 en 42:7-17) en 'n poëtiese middelstuk (Job 3:1-42:6) bestaan nie. Heelwat geleerdes is van mening dat die raamvertelling met ' $\mathrm{n}$ ou verhaal verband hou wat raakvlakke met ander Ou Nabye-Oosterse Jobverhale het (vgl Snaith 1968:19-33; Loader 1983:16-17). Hierdie ou verhaal het as basis gedien vir die skryf van die boek, wat tans uit ' $\mathrm{n}$ raamvertelling én ' $\mathrm{n}$ poëtiese middelstuk bestaan. Die ou verhaal het die vraag na lyding anders beantwoord as die huidige een. In die ou verhaal word die vergeldingsleer nie betwyfel nie, maar bevestig. Teen die einde van die verhaal ontvang Job dubbel soveel as wat hy vroeër verloor het. God seën (beloon) hom vir die feit dat hy volhard het om Hom te dien en nie in opstand gekom het nie. In die nuwe verhaal (synde die raamvertelling én die poëtiese middelstuk) word Job beloon ten spyte van die feit dat hy teen God in opstand gekom en Hom daarvan beskuldig het dat Hy Hom nie aan die vergeldingsleer hou nie, maar goddeloses en regverdiges oor een kam skeer (Job 9:22; 21:17-18). Die vriende, daarenteen, word bestraf ten spyte van die feit dat hulle God verdedig het (Job 11:6-12; 15:15-16; $22: 1-5)$. Teen die einde van die verhaal vind daar ' $n$ ironiese omkeer van verhoudinge plaas:

Aan die einde van die boek sit die vriende in presies dieselfde bootjie as die een waarin Job aan die begin gelaai was: Sonder dat hulle iets gedoen het om dit te verdien, beland hulle in die ongunstige posisie waarin Job was.

(Loader 1983:24) 
Dis ook moontlik om die stelling te maak dat die ouer Jobverhaal wat dormant in die raamvertelling lê, lyding as ' $n$ geloofstoets voorhou. God onderwerp Job aan 'n toets, en omdat hy dit slaag, word hy beloon. Die poëtiese middelstuk, daarenteen, beklemtoon dat lyding onverklaarbaar is. Job moet daarin berus dat God nie sy 'waarom-vrae' (Job 3) sal beantwoord nie. Na regte oorweldig God hom in die Godsredes (Job 38-41), en dwing hom tot onderdanigheid en aanvaarding van God se bestuur (Ehrman 2008:162-164). Volgens Loader (1983:25, 27) dwing God hom nie tot onderdanigheid nie, maar 'oorwin' Hy Job na Hom toe. Dit is ietwat positiewer geformuleer, maar ontkom nie aan die indruk wat die Godsredes laat nie: Hier is ' $n$ God aan die woord wat Hom nie deur 'n mens laat uitdaag nie.

Blom (2009:79-86) hanteer die Elihu-rede (Job 32-37) ook nie as ' $n$ latere toevoeging tot die boek nie, terwyl dit so duidelik soos daglig is dat dit ' $n$ latere toevoeging is. Daar is immers géén sprake van ' $n$ vierde vriend in die raamvertelling nie en hierdie hoofstukke onderbreek die samehang tussen Job 31 en Job 38 (Vriezen \& Van der Woude 1973:275). Slegs die drie vriende Elifas, Bildad en Sofar word by name vermeld (Job 2:11). Dit geld ook van die wysheidsgedig (Job 28). Dit pas nie in Job se mond nie, maar gryp vooruit op wat in die Godsredes (Job 38-41) gesê gaan word. Blom bespreek nie hierdie probleme nie, maar systap dit. Hy beskou sonder goeie redes Job 27-28 en Job 29-31 as twee slotredes van Job (Blom 2009:70-78). Hierdeur kyk hy die samehang wat tussen Job se klagte (Job 3) en Job se onskuldverklaring (Job 29-31) bestaan, mis.

Derdens neem hy die konteks waarin die boek ontstaan het nie ernstig genoeg op nie. Alhoewel hy erken dat die boek Job in die Persiese tydvak geskryf is, slaan hy nie ag op die moontlikheid dat dit binne' $n$ bepaalde sosiale en ekonomiese konteks tot stand gekom het nie (vgl Albertz 1981, 1990). Dis met dié kennis wat ek wil vra: Waarom kan die verhaal van Rut nie as agtergrond dien vir hoe Genesis 1-4 gelees behoort te word nie? Dit is eweneens in die Persiese tydperk geskryf en bring ook die vraag na God se verantwoordelikheid vir lyding ter sprake (Spangenberg 2005). Naomi wys ' $n$ vinger na God wanneer die dorpsvroue haar terugverwelkom en sy die verwelkoming afwys (Rut 1:19-21). Die skrywer van die boek Rut gaan egter anders as die skrywer van die boek Job te werk, al vertoon die twee verhale duidelike ooreenkomste (vgl Loader 1993, 1999). In die boek Rut is daar nie ' $n$ toneel wat in die hemel afspeel nie. Die skrywer skets die lewe soos ons dit ook ken - droogtes, misoeste, sterftes, maar ook liefde, getrouheid, medemenslikheid en omgee. En waar pas God in? In sowel die pyn van die verlede as in elke nuwe dag wat hoop verkondig; in mense wat die bul by die horings pak, deurdruk en met die lewe voortgaan soos Rut. 'n Antwoord op die vraag na lyding is niemand beskore nie, en om na ' $n$ antwoord te soek is sinneloos. Voorts is dit so dat net ' $n$ teïstiese Godsbeeld mense met onbeantwoorde vrae laat: 'Only if we confront the suffering in the world with belief in a loving, omnipotent God do we have hopeless haggling and questions without answers' (Weber 1998:78).

Die grootste probleem met Blom se bespreking van die boek Job hang egter saam met sy versweë aanvaarding dat die Godkarakter in die boek gelyk te stel is aan die Godkarakter van Genesis 1 en die Godkarakter van Genesis 2-4. Dis egter nie al nie. Hy stel hierdie Godkarakters ook gelyk aan die Godkarakter van die Christelike meesterverhaal. Dáárdie God straf mense vanweë die ongehoorsaamheid van 'n voorouer. Tog is dit nie hierdie God wat in Genesis 1-4 en in die boek Job aan die woord is nie. Blom neem nie die ontwikkeling van die Israelitiese godsdiens (soos ons dit uit die Israelitiese literatuur en die argeologiese opgrawings in Israel kan aflei) in ag nie. Hierdie godsdiens het eers gedurende die Babiloniese ballingskap werklik monoteïsties geword (Becking 2001:196; Spangenberg 2009:128-135). 'n Mens sou kon vra: Wys die skrywer van die boek Job met sy verhaal nie dalk die probleme uit wat met 'n monoteïstiese Godsbeskouing verband hou nie? So 'n Godsbeskouing maak God verantwoordelik vir goed én kwaad (Noort 1984). Die duiwelkarakter (of Satan) is juis in die Judaïsme en die Christelike geloof ingevoer om aan hierdie probleem te probeer ontsnap. In 'n politeïstiese Godsbeskouing word die probleem van wie vir die kwaad verantwoordelik is makliker hanteer. Een van die laervlakgode word daarvoor verantwoordelik gehou, terwyl die oppergod van alle blaam onthef word. Na my mening word daar te maklik in die teologie van 'die God van die Bybel' gepraat, sonder om die nuanses wat in die verskillende Bybelboeke na vore tree in ag te neem óf ag te slaan op die ontwikkelinge op godsdiensterrein. Blom gebruik weliswaar nie die benaming 'die God van die Bybel' nie, maar die ongenuanseerde wyse waarop hy die Godkarakters van die verskillende boeke en dele van boeke met mekaar in verband bring, bring hom in die nabyheid van so ' $n$ siening.

Ten spyte van hierdie kritiese opmerkings is Blom wél korrek wanneer hy uitwys dat Job se vriende volgens ' $n$ rigiede skema werk: die vergeldingsleer. Volgens hul oortuiging het goeie dade goeie gevolge, en slegte dade slegte gevolge, en kan hulle uit Job se lyding aflei dat hy sonde gedoen het. Tradisionele teoloë doen presies dieselfde, soos Blom tereg opmerk. Hulle werk met die rigiede reël van skepping-sondeval, aan die hand waarvan mense bepreek, hul handelinge verklaar en hul lewens benader word. In die slotsinne van die hoofstuk oor Job vat Blom (2009) dit goed saam:

In het dominante schema skepping - zondeval - verlossing staat de goedheid van de schepping, geschapen door een goede God, voorop. Het lijden en de dood zijn het gevolg van de zondeval en de zonde van de mens. Van deze zonde verlost God vervolgens de mens en hierbij past dat de mens zich bekeert tot God. Dit schema lijkt verdacht veel op het schema dat de vrienden hanteren in relatie tot Job.

(Blom 2009:120)

\section{GENESIS 1-4 GELEES MET DIE BOEK JOB IN DIE AGTERGROND}

Soos reeds uitgewys, bespreek Blom Genesis 1-4 in twee aparte hoofstukke van die proefskrif. Hoofstuk 3 handel net oor Genesis 1 en wat tradisioneel daaruit afgelei is, terwyl hoofstuk 4 net handel oor Genesis 2-4 en wat tradisioneel dááruit afgelei is. In sy bespreking van albei dele word die verhaal van Job betrek, en word daar vanuit dié boek se perspektief op God se verantwoordelikheid vir Job se lyding, oor kwaad in die skepping besin.

\section{Genesis 1}

In die openingsparagrawe van hoofstuk 3 beklemtoon Blom dat 'n noukeurige lees van Job uitgewys het dat die klassieke lees van Genesis nie ' $n$ stewige grondslag het nie. Teoloë en gewone Christene moet hulself afvra of die siening dat God 'n volmaakte skepping daargestel het wat deur menslike toedoen be-duiwel is, regtig vanuit Genesis 1-4 afgelei kan word. Die idee van skepping-sondeval-verlossing klink alte veel na die rigiede skema waarvolgens Job se vriende gewerk het; daarom wil hy Genesis nuut lees om te bepaal 'wat er wel en niet staat' (Blom 2009:121).

Met die lees van die inleidingsparagrawe het ek begin wonder of Blom nie (soos sy 'opponente') met ' $n$ korrespondensieteorie van die waarheid werk nie. Volgens hierdie teorie bied die teks lesers ' $n$ getroue blik op die werklikheid. Veral die volgende vraag laat 'n mens wonder: 'Een verwante vraag is: wat vult de klassieke lezing vanuit een bepaald beeld van God in en "wat heeft werkelijk grond in de teks zelf?"' (Blom 2009:121; klem toegevoeg). Dis egter nie al nie. Ook die eerste sin op die volgende bladsy roep vrae by ' $\mathrm{n}$ mens op: 'Het gaat hier om een nauwkeurig lezen van de tekst zoals wij die nu in de canon hebben' (Blom 2009:122). Hy kies vir ' $n$ sinchroniese lees van die teks, en laat ' $n$ diachroniese lees daarvan grootliks buite rekening. Oor die 
oorsprong en die samevoeging van die twee skeppingsverhale (Gen 1:1-2:4a \& Gen 2:4b-3:24) laat hy hom nie uit nie, en oor die probleme rondom die groei van die kanon, en die feit dat daar verskillende kanons bestaan, besin hy nie. Hy haal uit die Hebreeuse Bybel (Biblia Hebraica Stuttgartensia) aan en ignoreer die feit dat hierdie kanon nie gelyk te stel is aan die Protestantse kanon van die Ou Testament nie (vgl Deist 1989).

Voordat hy met sy lees van Genesis 1 begin, gee hy die klassieke interpretasie, wat in die sewe punte hierbo vermeld is, weer. Die eerste punt wat in hoofstuk 3 aan die orde kom, is 'skepping uit niks' (Gen 1:1), en sy gevolgtrekking ná sy lees en bespreking daarvan is dat die teks nie so ' $\mathrm{n}$ interpretasie ondersteun nie. Ons kan ook nie op grond van hierdie teks redeneer dat aangesien God goed is, dit die 'goedheid van die skepping' waarborg nie (Blom 2009:129). Na regte is Genesis 1:1 slegs ' $n$ openingsvers, en begin die eintlike skeppingsverhaal eers met Genesis 1:2. Dit beskryf die toestand van die wêreld voordat God met sy skeppingswerk begin het. Dáárdie wêreld was 'woes en leeg'. Wat laasgenoemde vers betref, is daar volgens hom vyf kategorieë van interpretasie:

- Die vers beskryf die toestand van die skeppingsmateriaal. Ons behoort dit nie met kwaad, die bose of die slegte in verband te bring nie.

- Die vers weerspieël iets van die chaosstryd (Chaoskampf) wat so kenmerkend van Ou Nabye-Oosterse skeppingsverhale is. God oorwin die chaosmagte deur sy skeppingsdaad.

- Die vers beskryf die wêreld vóór die skepping. Dit is ' $n$ ruwe en weerspannige wêreld wat nie bevorderlik is vir lewe nie. Die skepping is geneig om weer na die ruwe en weerspannige toestand terug te val.

- Die vers beskryf nie werklik ' $n$ toestand nie, maar maak slegs ' $n$ stelling dat die eintlike skepping nog nie begin het nie.

- Die vers beskryf ' $n$ wêreld waarop God sy rug gekeer het. Dit is die teendeel van die skepping, en kom na vore waar God en sy skepping verwerp word.

Blom gee toe dat hierdie vyf interpretasies nie in waterdigte kompartemente bestaan nie, maar soms oorvleuel. Dit kan ' $n$ mens egter help om sinvol oor Genesis 1:2 te praat. In sy verdere bespreking fokus hy op drie geleerdes se omgang met Genesis 1 en spesifiek hierdie vers. Hulle is Levenson, Noordmans en Barth. Al drie dié geleerdes is van mening dat die kwaad van die begin af bestaan het. Blom (2009) som dit só op:

Dit kwaad is verbonden met de voorwereld van vers 2 , die tegenover de schepping staat. Het kwaad is niet iets dat pas met de zondeval in de wereld gekomen is.

(Blom 2009:141)

Die mens is dus nié verantwoordelik vir die kwaad wat bestaan nie. Desnieteenstaande lê elkeen van die vermelde geleerdes ' $n$ ander klem wat God se betrokkenheid by en verantwoordelikheid vir die kwaad betref.

Blom toets hierdie verstaan van Genesis 1:2 ook aan ander gedeeltes in die Ou Testament, en bring Job 38:8-11, Spreuke 8:22-31 en Psalm 104 ter sprake. In hierdie gedeeltes is daar sprake daarvan dat God aan die chaoswaters 'n grens gestel het. Dit klop volgens hom met wat in Genesis 1:2 oor die voorwêreld gesê word. Vóór die skepping van die mens was daar reeds kwaad (gesimboliseer deur die chaoswaters); dit het nie eers ná die sondeval na vore getree nie. Verder is dit duidelik dat God oor die mag beskik om 'n grens daaraan te stel. Die chaoswaters waarvan in hierdie dele sprake is, roep op sy beurt die kwessie van die chaosstryd op, en daarom wy Blom heelwat aandag hieraan. Volgens hom word die volledige mitologiese verhaal van God se stryd met die chaosmagte nêrens in die $\mathrm{Ou}$ Testament vertel nie (Blom 2009:157). Daar is slegs maar dele in die $\mathrm{Ou}$ Testament wat met motiewe uit hierdie verhaal werk. Die chaosmagte word nooit as God se gelyke of as magtiger as God voorgehou nie. In die wêreld vóór die skepping was daar chaos (kwaad). God het egter sy rug daarop gekeer, en geskep. Hy het nie met die chaos ' $n$ stryd gevoer om die kosmos te maak nie.
Dis duidelik dat Blom (2009) aansluiting vind by die geleerdes wat tuis is in die vyfde interpretasie hierbo, en hy verwoord dit soos volg:

Er valt hier dus iets te zeggen voor Barths interpretatie dat hier een wereld beschreven wordt die God verwerpt. Op dit verwerpen ligt in Genesis 1 niet veel nadruk. Het accent ligt op het scheppen van een goede wereld.

(Blom 2009:161)

Na my mening lees Blom (cum sui) méér in hierdie teks as wat dit toelaat. Ons kry hier met 'eisogese' te doen. Hieroor skryf Hoffmann (1993:241) soos volg: "Eisogesis" - the skill of reading out of the text the interests we read into it - is a well-developed habit in theological circles.' Genesis 1:2 gee nie ' $n$ feitelike verhaal van wat vóór die skepping bestaan het nie. Genesis 1 is 'n Israelitiese skeppingsverhaal wat nie antwoorde kan gee op vrae wat latere teoloë bedink het nie. Genesis 1 kan ook nie antwoorde voorsien op vrae wat evolusionêre bioloë tans vra nie. Die skrywer van die verhaal het met ' $n$ verouderde wêreldbeeld en met beperkte insig geskryf. Dis hoe hý die skepping verstaan het. Ons het nie hier met 'n objektiewe beskrywing te doen nie, maar met 'n subjektiewe een, en daarom kan ons nie 'ewige waarhede' of 'geopenbaarde waarheid' daaruit aflei nie.

Ruimte laat dit nie toe om hier op al die ander sake wat Blom (2009) in die hoofstuk bespreek in te gaan nie, behalwe die idee dat die mens beelddraer van God is. Hieroor skryf hy soos volg:

Traditioneel neemt de leer van de mens als beeld van God in de christelijke theologie een centrale plaats in: het wordt als de belangrijkste uitspraak over de mens beschouwd en deze uitspraak vormt in menige antropologie het uitgangspunt. De mens als beeld van God drukt dan het diepste wezen van de mens uit, de mens zoals God die oorspronkelijk geschapen heeft.

(Blom 2009:180)

In sy bespreking van hierdie saak slaan hy ag op wat Calvyn, Rüterwörden, Neumann-Gorsolke en Brueggemann oor die mens as beelddraer geskryf het.

Calvyn tref ' $\mathrm{n}$ onderskeid tussen die mens soos God hom aanvanklik geskep het, en die mens ná die sondeval (Blom 2009:181-183). Die mens was aanvanklik 'n perfekte beelddraer (goed en volmaak), maar ná die sondeval is hy hierdie perfeksie kwyt. Dit strook met hoe daar tradisioneel in die Westerse Christendom oor die mens gedink is.

Rüterwörden erken dat Genesis 1 tot die P-materiaal van die Pentateug behoort, en hy interpreteer 'beeld van God' nie as ' $n$ uitspraak oor die wese van die mens nie, maar as ' $n$ uitspraak oor die funksie wat hy in die skepping moet vervul. Die mens moet soos ' $n$ koning met verantwoordelikheid oor die diere heers. Hy lê dus nie ' $n$ verband tussen Genesis 1 en Genesis 2-3 nie, maar hanteer Genesis 1 as 'n skeppingsverhaal uit eie reg wat ons iets oor die mens se verantwoordelikheid meedeel.

Neumann-Gorsolke sebeskouings lêna aan diévan Rüterwörden. Sy bespreek Genesis 1 ook as deel van die P-materiaal, en deel die oortuiging dat 'beeld van God' 'n uitspraak oor die funksie van die mens is. Die mens moet oor die skepping heers. Blom (2009) gee Neumann-Gorsolke se sienings soos volg weer:

Het gaat bij de mens als beeld van God om een functie, niet om een afbeelding van God alsof God in dit beeld vastgelegd zou kunnen worden. Het gaat hier om representatie. De mens is Gods verteenwoordiger op aarde.

(Blom 2009:187)

Brueggemann heg nie groot waarde aan die uitdrukking 'beeld van God' nie, want volgens hom speel dit nie in die Ou Testament werklik ' $n$ rol nie. Blom meen egter dat Rüterwörden en Neumann-Gorsolke se sienings groter gewig dra as Brueggemann s'n, en daarom kyk hy self deeglik na Genesis 1:26-28. Sy studie van hierdie verse lei daartoe dat hy die tradisionele Christelike verstaan van 'beeld van God' (naamlik dat dit met die mens se onskuld en sy aanvanklike perfekte 
verhouding met God saamhang) afwys. Die sondeval het ook nie hierdie 'beeld-van-God-wees' geskend nie. Hy som dit soos volg op:

Een eerste conclusie op basis van bovenstaande gegevens is dat deze traditionele interpretatie geen recht doet aan Genesis 1. Deze interpretatie haalt er elementen bij die in Genesis 1 nie aanwezig zijn. Verder lijkt van enige schade aan of verlies van dit beeld van God in Genesis geen sprake te zijn. Zowel in Genesis 5 als in 9 is de mens nog volop beeld van God.

(Blom 2009:195)

Blom (2009) kies uiteindelik vir Rüterwörden en NeumannGorsolke se sienings, en skryf dan:

De klassieke en substantiële interpretatie is dus geen goede interpretatie van Genesis 1:26 en verder, wanneer we deze verzen lezen tegen de achtergrond van het Oude Testament en Oude Nabije Oosten.

(Blom 2009:212)

Hierdie hoofstuk van die proefskrif getuig (soos die vorige een) van deeglike navorsing, maar, net soos dáár, sit 'n mens hier met vrae - veral ten opsigte van Blom se verstaan van Genesis 1:2. Die vers gee nie ' $n$ objektiewe beskrywing van die wêreld vóór die eintlike skepping nie. Daarom kan ons dit nie gebruik om allerlei dogmatiese stellings oor hierdie 'voorwêreld' te maak nie. Oor die kwessie van 'beeld-van-God-wees' wat moontlik met die koningsideologie van die Ou Nabye Ooste saamhang, en dus op die mens se funksie in die skepping dui, is daar vir my minder besware te opper. Die verteller van die verhaal plaas die mens wél in ' $n$ heersersposisie ten opsigte van die res van die skepping. Dié soort mensbeskouing moet egter met omsigtigheid gebruik word, want ons weet tans dat die mens in die web van die lewe veranker is. Volgens die evolusionêre biologie is hy nóg die kroon van die skepping nóg heerser oor alles.

\section{Genesis 2-4}

Aan die begin van sy bespreking van Genesis $2-4$ maak Blom dit duidelik dat hy nie die siening deel dat Genesis $2: 4 b-3: 34$ 'n tweede skeppingsverhaal is nie: 'Genesis 2 heeft elementen die thuishoren in een scheppingsverhaal, maar het lijkt geen scheppingsverhaal te zijn' (2009:219). Die tuinverhaal is volgens hom ' $n$ voortsetting van die skeppingsverhaal wat ons in Genesis 1 vind. Dis ' $n$ soort uitbreiding. Ek vind sy redenasie ter verdediging van dié soort siening nie oortuigend nie. Eerstens is dit duidelik dat die eerste skeppingsverhaal met Genesis 2:4a eindig. Dit bevat immers die tōledōt-formule, wat die grense van die verskillende dele in Genesis aandui (Fokkelman 1989:41-42). Tweedens is dit so duidelik soos daglig dat die Godkarakter van hierdie verhaal en die Godkarakter van Genesis 1 nie dieselfde karakter is nie. Die Godkarakter in Genesis 1 is verhewe, en skep die mens deur te spreek (Gen 1:26-29), terwyl die Godkarakter in Genesis 2-3 die mens maak deur klei te gebruik (Gen 2:7), en dan maak Hy eers net ' $n$ man soos Hy self is. Blom (2009:219) is wél reg deur daarop te wys dat die tradisionele interpretasie Genesis $1-3$ as ' $n$ eenheid lees. In die Ou-Testamentiese wetenskap word dit egter nie meer só hanteer nie. Genesis 1 hou verband met die P-materiaal van die Pentateug, en Genesis 2-3 met die J-materiaal daarvan (Westermann 1972:13, 26-27). Hierdie materiaal is op verskillende tye in Israel se geskiedenis deur verskillende skrywers geskryf. Ons moet dus die nuanses respekteer.

Net soos in die vorige twee hoofstukke, kies Blom ' $n$ aantal geleerdes wat die weg tot verdere bespreking moet baan. In hierdie geval is dit Hegel, Barr en Stordalen (Blom 2009:221-228). Hegel onderskryf nie die tradisionele interpretasie van Genesis 2-3 nie, maar wys daarop dat die verhaal te kenne gee dat daar groei/ontwikkeling by die mens moet plaasvind. Barr wys op sy beurt ook daarop dat die tuinverhaal niks met ' $n$ sondeval te doen het nie. Die verteller toon slegs dat die mens so byna onsterflikheid bekom het, maar dit deur sy vingers laat glip het deur van die boom van kennis te eet. Stordalen meen weer dat die gedeelte in die vroeë Persiese tyd geskryf is en dat die twee bome in die tuin twee tipes godsdiens verteenwoordig:

De levensboom staat voor de officiële gesanctioneerde godsdienst, waar de goden duidelijke karakters hebben en alles duidelijk omschreven is. De boom van kennis staat voor inofficiële religie met mantiek en chtonische goden.

(Blom 2009:227)

Die verteller vermaan die Jode van die na-ballingskaptyd, en wys daarop dat indien hulle iets van die tuin van Eden wil ervaar, hulle die Jahwisme moet aanhang en alle mantiek en dergelike gebruike moet laat links lê (Blom 2009:227).

Soos in die vorige hoofstukke, roer Blom heelwat sake aan, maar dit is nie moontlik om hier oor alles verslag te doen en op alles kommentaar te lewer nie. Wat wél van belang is, is wat hy oor die mens en die sogenaamde sondeval skryf. Die mens word hier van 'stof' gemaak, en dít dui volgens hom op die mens se nederigheid, broosheid, kwesbaarheid en verganklikheid (Blom 2009:232). Die mens was van die begin van die skepping dus sterflik, en het nie vanweë 'n sondeval sterflik geword nie. Die wyse waarop die mens in hierdie gedeelte geskets word, wek die indruk dat die man en vrou byna soos kinders is. Hulle het nog nie die nodige lewenservaring en kan nog nie deurdagte besluite neem nie:

Er lijkt hier dus gezinspeeld te worden op een situatie als die van kinderen, die nog volwassen moet worden. In het licht hiervan lijkt het juist positief, wanneer de mens kennis krijgt van goed en kwaad.

(Blom 2009:236)

Die slang speel ' $n$ positiewe rol in die vertelling, en nie ' $n$ negatiewe rol soos in die tradisionele interpretasie nie. Hy help die mense om wysheid te bekom (Blom 2009:242). Dít wat hy aan die mens kommunikeer, naamlik 'julle sal soos God word', word uiteindelik deur die Godkarakter van die verhaal bevestig wanneer Hy sê: 'Die mens het nou soos een van Ons geword ...' (Gen 3:22). Hierdie 'word soos God' kom wel teen 'n prys. Elkeen van die karakters wat by die gebeure betrokke was, moet egter ' $n$ verskillende prys betaal. Die slang verloor sy vermoë om te loop en moet vir die res van sy lewe op sy maag seil. Die vrou sal vir altyd tot haar man aangetrokke voel en sal met moeite aan haar kinders geboorte gee. Die man sal van nou af hard moet werk, en die aarde sal weerspannig wees. Die opmerking '... totdat jy terugkeer na die aarde' (Gen 3:19) is nie deel van die prys wat die man moet betaal nie, maar slegs ' $n$ saaklike opmerking.

Blom maak hier 'n paar bokspringe wanneer hy tussen dood en sterflikheid onderskei, en skryf: 'In het Oude Testament is de dood regelmatig een straf, maar dit geldt niet voor de sterfelijkheid' (2009:248). Na my mening tref van die skrywers van die Ou Testament ' $n$ onderskeid tussen dood wat op die regte tyd kom (ná 'n voorspoedige en lang lewe) en dood wat voortydig kom ('n vroeë dood met geen nageslag nie). Laasgenoemde word nie positief beleef nie, maar dit word ook nie konsekwent as straf gereken nie (Spangenberg 1988:30-31)

In die hoofstuk oor Kain en Abel (Gen 4) bespreek Blom kortliks die probleem rondom die aanvaarding en afkeuring van die twee broers se offers (2009:255-257). Kain slaan sy broer, Abel, dood in reaksie op God se minagting van Kain se offer. Die verhaal voorsien nie redes vir God se reaksie nie, en uitleggers doen ook hiér vyf moontlike verklarings aan die hand. Nie een is regtig bevredigend nie, want die teks voorsien nie ' $n$ antwoord nie. Weinig uitleggers wys daarop dat die verteller se Godkarakter dieselfde een is wat in Genesis 2-3 so uiters menslik optree. Dáár is Hy ten volle geklee, terwyl Adam en Eva naak rondloop. Eers ná die eet van die vrug kom Adam en Eva met ontnugtering agter dat hulle al die tyd naak was terwyl God ten volle geklee rondgewandel het! (Laasgenoemde sinne is nie Blom s'n nie, maar die skrywer van die artikel s'n.) Blom self ignoreer die inligting dat die Godkarakter van die tuinverhaal ' $n$ bedrewe kleremaker is (Gen 3:21), en maak niks met hierdie inligting in die verhaal nie. Dit is nie genoeg om te erken dat die J-verteller 
lief is om God antropomorf voor te stel nie (Houtman 1980:213). Die Godkarakter van Genesis 1-4 is menslik; daarom is dit goed om Fokkelman (1999:58) se opmerking hier nie uit die oog te verloor nie: 'In narrative texts God is a character, i.e. a creation of the narator and writer."

In sy finale gevolgtrekking bring Blom weer die boek Job ter sprake en wys daarop dat diegene wat God se handelinge in Genesis 2-4 wil verdedig of verklaar na regte soos Job se vriende optree (Blom 2009:258). Dan maak hy hierdie stelling:

We vinden in Genesis 2-4 geen duidelijke verkaveling van verantwoordelijkheden tussen God en mens. De mens zondigt hier, maar dit is niet het hele verhaal. God plaatst de mens in een situatie die leidt tot die zonde, zonder dat hierbij sprake is van oorzaak en gevolg, waarbij de zonde wel moet volgen. Het is eerder zo dat de grenzen niet scherp zijn.

(Blom 2009:259)

Blom (2009) wil die mens nie alleenverantwoordelik maak vir wat binne en buite die tuin gebeur het nie, maar hy wil ook nie die volle blaam op God plaas nie:

Zowel in Genesis 2-3 als in Genesis 4 plaatst de Heer de mens in een situatie die leidt tot het eten van de boom van de kennis van goed en kwaad en de moord op Abel.

(Blom 2009:260)

God het dus wél ' $n$ aandeel, maar dit is moeilik om te verwoord.

\section{GEVOLGTREKKING}

\section{Daar was geen sondeval nie - maar wat daarvan?}

Uit die voorafgaande behoort dit duidelik te wees tot watter gevolgtrekking Blom gaan kom: Wanneer ' $\mathrm{n}$ mens Genesis 1-4 noukeurig lees, blyk dit dat daar nie sprake is van 'n sondeval nie. Hy spel egter nie uit watter gevolge dit vir die tradisionele Christelike geloof inhou nie. Wat is die konsekwensies indien ' $n$ mens die idee van erfsonde prysgee? Wat maak ons met die Heidelbergse Kategismus (Sondag 5 \& 6) wat Jesus as onaangetas deur die erfsonde voorhou? Hoe moet ons nou oor Jesus se menswees nadink? Is dit nog nodig om daarop aan te dring dat Hy uit ' $n$ maagd gebore is? Moet ons nie maar erken dat Jesus volledig mens was soos ons nie? Hoe raak dít alles die Westerse Christendom se versoeningsleer?

Blom se navorsing is vir my nie verrassend nuut nie - wél die manier waarop hy te werk gegaan het om by sy gevolgtrekking uit te kom. Verskeie Ou-Testamentici het al uitgewys dat die tradisionele interpretasie van Genesis 1-3 nie steekhoudend is nie (vgl Spangenberg 2007). Selfs sistematiese en praktiese teoloë begin dit erken. Neem as voorbeeld Dingemans (2000:350), wat skryf: 'Er is in de bijbel geen sprake van "erfzonde!"'

Blom wil grond onder sy voete hê om afskeid te neem van die idee van ' $n$ sondeval. Hy soek in die Bybel na hierdie grond, en vind dit natuurlik ook. Die boek Job gee vir hom 'n sleutel om Genesis 1-4 mee te interpreteer. Die wyse waarop hy te werk gaan, getuig van indringende studie, maar tog is daar (soos reeds uitgewys) probleme daaraan verbonde. Die probleme kan na my mening teruggevoer word na die Skrifbeskouing wat hy as uitgangspunt gebruik: Die Bybel is die Woord van God, en dis op grond daarvan dat ons teologiese sekerheid kan kry. Voorts werk hy met ' $n$ korrespondensieteorie van die waarheid: Die teks gee ons direkte toegang tot die werklikheid. Dít is waarom hy soveel maak van Genesis 1:2, wat volgens hom die 'voorwêreld' voor die skepping beskryf. Laastens maak hy in sy ontledings van die hoofstukke gebruik van narratiewe analises. Dié soort omgang met die Bybelse materiaal rym egter moeilik met die tradisionele Skrifbeskouing. Hy onderskei byvoorbeeld nie tussen die verskillende Godkarakters in die vertellings nie, maar maak asof almal dieselfde God beskryf - die VaderSkeppergod van die Christelike geloof.
Die Bybel is nie die Woord van God wat ná intensiewe studie antwoorde op ons teologiese vrae bied nie (Barr 1973:142). Die Bybel is volledig ' $n$ menslike boek, en ons wat dit interpreteer bly vasgevang in ons subjektiewe interpretasies. Ons kan selfs nie enige objektiewe uitsprake oor God maak nie (Kennedy 2006:255).

Blom probeer met sy proefskrif uit die greep van die sondeval kom en doen afstand van die idee dat die mens skuld vir al die kwaad in die wêreld moet dra. Hy gee egter nie die Augustiniaanse paradigma van die teologie totaal prys nie, maar bly daarin vasgevang. Dít blyk uit sy aanvaarding dat Genesis 1-4 en die boek Job oor dieselfde God handel: die Vader-Skeppergod van die Christelike tradisie.

\section{LITERATUURVERWYSINGS}

Albertz, R., 1981, ‘Der sozialgeschichtliche Hintergrund des Hiobbuches und der "Babylonischen Theodizee" [Die sosiaalwetenskaplike agtergrond van die boek Job en die Babiloniese Teodisee]', in J. Jeremias \& L. Perlitt (Hrsg.), Die Botschaft und die Boten: Festschrift für Hans Walter Wolff zum 70. Geburtstag, pp. 349-372, Neukirchener Verlag, Neukirchen-Vluyn.

Albertz, R., 1990, 'The Sage and Pious Wisdom in the Book of Job: The Friends' Perspective [Die wysheidsgeleerde en tradisionele wysheid in die boek Job: Die vriende se perspektief]', in J.G. Gammie \& L.G. Perdue (eds.), The Sage in Israel and the Ancient Near East, pp. 243-261, Eisenbrauns, Winona Lake.

Barr, J., 1973, The Bible in the Modern World [Die Bybel in die moderne wêreld], SCM, London.

Becking, B., 2001, 'Only One God: On Possible Implications for Biblical Theology [Slegs een God: Oor moontlike gevolge vir 'n bybelse teologie]', in B. Becking, M. Dijkstra, M.C.A. Korpel \& K.J.H. Vriezen (eds.), Only One God? Monotheism in Ancient Israel and the Veneration of the Goddess Asherah, pp. 189-201, Continuum, London.

Bezuidenhout, L.C., 1986, 'Struktuur en strekking van die boek Job', ongepubliseerde proefskrif, Departement Semitiese Tale, Universiteit van Pretoria.

Blom, C., 2009, Zonder grond onder de voeten: Een theologische analyse van het boek Job en Genesis 1-4 vanuit het perspektief van het kwaad in de schepping [Geen grond om op te staan: ' $n$ Teologiese ontleding van die boek Job en Genesis 1-4 vanuit die perspektief van kwaad in die skepping], Boekencentrum Academic, Zoetermeer.

Deist, F.E., 1989, 'Is die Masoretiese teks die Ou Testament?', Skrif en Kerk 10, 9-20.

Den Heyer, C.J., 2003, Van Jezus naar christendom: De ontwikkeling van teks tot dogma [Van Jesus tot Christendom: Die ontwikkelinge vanaf teks tot dogma], Meinema, Zoetermeer.

Dingemans, G.D.J., 2000, De stem van de Roepende: Pneumatheologie [Die stem van die Roepende: Pneumateologie/ 'n Teologie vanuit die perspektief van die Gees], Kok, Kampen.

Durand, J.J.F., 1978, Die Sonde, NG Kerkboekhandel, Pretoria.

Ehrman, B., 2008, God's Problem: How the Bible Fails to Answer Our Most Important Question - Why We Suffer [God se probleem: Hoe die Bybel faal om die belangrikste vraag te beantwoord - waarom die mens ly], HarperCollins, New York.

Fokkelman, J.P., 1989, 'Genesis', in R. Alter \& F. Kermoe (ed.), The Literary Guide to the Bible, pp. 36-55, Fontana, London.

Fokkelman, J.P., 1999, Reading Biblical Narrative: A Practical Guide [Om bybelse narratiewe te lees: ' $n$ Praktiese gids], Deo Publishing, Leiden.

Hoffmann, R.J., 1993, 'Afterword [Na woord]', in M. Smith \& R.J. Hoffmann (eds.), What the Bible Really Says, pp. 239-243, HarperSanFrancisco, San Francisco. 
Houtman, C., 1980, Inleiding in de Pentateuch [Inleiding in die Pentateug], Kok, Kampen.

Kennedy, P., 2006, A Modern Introduction to Theology: New Questions for Old Beliefs ['n Moderne inleiding in die teologie: Nuwe vrae vir ou geloofsoortuigings], I.B. Tauris, London.

Loader, J.A., 1983, 'Job - antwoord of enigma?', Theologia Evangelica (Suid-Afrika) 16(2), 15-31.

Loader, J.A., 1993, 'Job's sister: Undermining an unnatural religiosity [Job se suster: Ondermyning van 'n onnatuurlike godstienstigheid]', Old Testament Essays 6, 312-329.

Loader, J.A., 1999, 'Noomi und Hiob, Schubert und Mahler: Überlegungen $\mathrm{zu}$ einem alttestamentlichen Beitrag in Wien [Naomi en Job, Schubert en Mahler: Gedagtes oor OuTestamentiese navorsing in Wenen]', in J.A. Loader \& H.V. Kieweler (Hrsg.), Vielseitigkeit des Alten Testaments: Festschrift für Georg Sauer zum 70. Geburtstag, pp. 149-163, Peter Lang, Wien.

Noort, E., 1984, 'JHWH and das Böse: Bemerkungen zu einer Verhältnisbestimmung [JHWH en die kwaad: Aantekeninge oor die verhouding tussen die twee]', in A.S. Van der Woude (ed.), Prophets, Worship and Theodicy: Studies in Prophetism, Biblical Theology and Structural and Rhetorical Analysis and on the Place of Music in Worship, pp. 121-136, Brill, Leiden.

Snaith, N.H., 1968, The Book of Job: Its Origin and Purpose [Die boek Job: Sy oorsprong en doel], SCM, London.
Spangenberg, I.J.J., 1988, 'Die Prediker se uitsprake oor en uitkyk op die dood', Scriptura 27, 29-37.

Spangenberg, I.J.J., 2005, 'Constructing a historical context for the Ruth novelette: Dovetailing the views of Rainer Albertz and James Alfred Loader [Om 'n historiese konteks vir die Rutnovelle te konstrueer: Versmelting van die sieninge van Rainer Albertz en James Alfred Loader]', Old Testament Essays 18, 345-355.

Spangenberg, I.J.J., 2007, 'Can a major religion change? Reading Genesis $1-3$ in the Twenty-First Century [Kan 'n groot godsdiens verander? Om Genesis 1-3 in die eenen-twintigste eeu te lees]', Verbum et Ecclesia 28, 259279.

Spangenberg, I.J.J., 2009, 'Yahwism, Judaism and Christianity: religions do evolve! [Jahwisme, Judaïsme en Christelike godsdiens: Godsdienste evolueer inderdaad!]', in C.W. du Toit (ed.), The Evolutionary Roots of Religion: Cultivate, Mutate or Eliminate?, pp. 119-143, Unisa, Pretoria.

Vriezen, Th C. \& Van der Woude, A.S., 1973, Literatuur van OudIsraël, Wassenaar, Servire.

Weber, G., 1998, I believe. I doubt. Notes on Christian Experience [Ek glo. Ek twyfel. Aantekeninge deur 'n Christen], SCM, London.

Westermann, C., 1972, Genesis 1-11, WBG, Darmstadt. 